\title{
$\mathrm{Hg}^{2}+$ 胁迫对浮萍体细胞 DNA 一级结构 和抗氧化酶系的损伤
}

徐 楠 施国新 曾晓敏 丁小余 徐勤松 陈 源

(南京师范大学生命科学学院, 南京 210097)

\begin{abstract}
摘 要 主要从 DNA一级结构及抗氧化酶系变化两方面, 研究了 $\mathrm{Hg}^{2+}$ 胁迫下浮萍体细胞的损伤。结果表明 运用 随机扩增多态性 DNA 法 (Random amplified polymorphism DNA, RAPD) 和 DNA 梯法 (DNA Ladder) $5 \sim 10 \mathrm{mg} \mathrm{L} \mathrm{L}^{-1} \mathrm{Hg}^{2+}$ 处理组可检测到基因组 DNA 的明显损伤 $20 \mathrm{mg} \mathrm{L}^{-1} \mathrm{Hg}^{2+}$ 已导致细胞坏死 ;RAPD 法较 DNA Ladder 法更灵敏。本文 还发现, 活性氧和抗氧化酶系很可能参与了浮萍体细胞凋亡过程。低浓度的 $\mathrm{Hg}^{2}$ 胁迫可刺激抗氧化酶活性升高, 以清除体内活性氧, 而一旦活性氧水平超出一定域值, 抗氧化酶活性急速下降, 导致细胞凋亡。
\end{abstract}

关键词 $\mathrm{Hg}^{2+}$ 浮萍 DNA 损伤 抗氧化酶 RAPD DNA Ladder

\section{DAMAGE TO DNA PRIMARY STRUCTURE AND ANTIOXIDANT ENZYMES IN LEMNA MINOR INDUCED BY HG $^{2+}$}

\author{
XU Nan SHI Guo-Xin ZENG Xiao-Min DING Xiao-Yu XU Qin-Song and CHEN Yuan \\ ( College of Life Sciences , Nanjing Normal University, Nanjing 210097 , China)
}

\begin{abstract}
The damage to Lemna minor cells induced by $\mathrm{Hg}^{2+}$ was studied in this article. Most damage occurred to DNA primary structure and changes in antioxidant enzyme activities were investigated by using RAPD and DNA ladder methods. The results showed that obvious damage to DNA was found in the process of apoptosis induced by 5-10 mg L ${ }^{-1} \mathrm{Hg}^{2+}$, and $20 \mathrm{mg} \mathrm{L}^{-1} \mathrm{Hg}^{2+}$ had already caused necrotic injury. The RAPD method was the more sensitive of the two methods , and so could be considered as an important method for monitoring apoptosis. The results also indicated that reactive oxygen species (ROS) and antioxidant enzymes are involved in the process of apoptosis. The activities of antioxidant enzymes could be stimulated to eliminate active oxygen by exposing the Lemna minor to low $\mathrm{Hg}^{2+}$ concentration ; the cells declined rapidly when ROS were unable to be eliminated effectively.
\end{abstract}

Key words $\mathrm{Hg}^{2+}$, Lemna minor , DNA damage , Antioxidant enzymes , RAPD , DNA Ladder

Atmospheric deposition, geology and mineral resources seeping and untreated industrial effluent can cause heavy metal pollution in water. $\mathrm{Hg}^{2+}$, as one of the major heavy-metal pollutants, not only has poisoning effects on plant (Wu et al. 1997), but also can enter the food chain, and serve as potential threat to the human health (Sugiyama ,1994). So far, the effects of heavy metal pollution on submerged plants focused mostly on the growth process and the physiological effects (Shi et al . 2000 ; Korichera et al .,1997 ;Zhang et al .,1999). But few studies has been done on apoptosis of plants induced by heavy metal(Meyer \& Heath ,1988 ;Schutzendubel et al . , 2001). Let alone the mechanism of DNA damage and changes of antioxidant enzyme activities in Lemna minor L. cell.
Lemna minor L. is a kind of fluitante belonging to Lemnaceae. It widely spreads over China and is very sensitive to the pollutants, so it is generally thought as a sensitive plant for environment monitoring( Tong 1997). The aim of this work was to study the damage mechanism of DNA primary structure and antioxidant enzymes in the apoptosis process induced by $\mathrm{Hg}^{2+}$ in Lemna minor $\mathrm{L}$. , and to investigate the toxic mechanism of heavy metal to plants.

\section{Materials and methods}

\subsection{Material and culture method}

Lemna minor L. was collected in June 2001 ( 25 ${ }^{\circ} \mathrm{C}$ ) in Xingdian town, Nanjing. The samples in good growth potential were selected and pre-cultured in the 
deionized water for $2 \mathrm{~d}$. Then they were treated with different $\mathrm{Hg}^{2+}$ concentration of $0,5,7,10,20 \mathrm{mg} \mathrm{L} \mathrm{L}^{-1}$ at 9:00 in the morning. All the specimen were cultivated in Forma-3744 light culture box (made in USA). Temperature was $(25.0 \pm 0.5)^{\circ} \mathrm{C} /(15.0 \pm 0.5)^{\circ} \mathrm{C}$ ( day/night) , light intensity was $70 \mu \mathrm{mol}$ photons $\mathrm{m}^{-2} \mathrm{~s}^{-1}$, and photoperiod was $12 \mathrm{~h} / 12 \mathrm{~h}$. Since the sixth day , the leaves , $5 \mathrm{~mm}$ in diameter, were used to detect DNA damage and antioxidant enzyme activities. Each experiment was repeated for three times.

\subsection{DNA extraction}

$0.2 \mathrm{~g}$ of leaf-tissue was firstly washed in sterile deionized water for $2 \mathrm{~min}$. After being air dried, the sample was ground into powder in liquid-nitrogen with mortar and pestle. DNA was extracted from the sample using a modified CTAB (Cetyltrimethylammonium bromide) procedure (Rogers \& Bendich , 1985), some of which was ameliorated in this paper. The powdered leaf-tissue was added to $0.6 \mathrm{ml}$ CTAB extraction buffer ( $2 \%$ CTAB $; 1.4$ mol $\mathrm{L}^{-1} \mathrm{NaCl} ; 1 \% \mathrm{PVP} ; 100$ mmol L L ${ }^{-1}$ Tris-HCl , $\mathrm{pH}$ $8.0 ; 20$ mmol $\mathrm{L}^{-1}$ EDTA ; 0.2\% 2-mercaptoethanol). The suspension was incubated in a water bath at $60{ }^{\circ} \mathrm{C}$ for 45 min with occasional shaking, then cooled to room temperature and extracted with one vol. chloroform/isoamyl alcohol (24:1) for $10 \mathrm{~min}$. After centrifugation at 5600 $\mathrm{g}$ for $10 \mathrm{~min}$, the supernatant was extracted by chloroform/isoamyl alcohol extraction once more. The two phases were separated by centrifugation, and 2.5 vol. dehydrated alcohol was added to the supernatant , $-20{ }^{\circ} \mathrm{C}$ depositing for $2 \mathrm{~h}$. Then the mixture was centrifugatized at $8600 \mathrm{~g}$ for $15 \mathrm{~min}$. The pellet was washed with $70 \%$ ethanol twice, then dissolved in sterilized TE $(1 \mathrm{~mol} / \mathrm{L}$ Tris-HCl 0.1 mol $\mathrm{L}^{-1}$ EDTA ,pH 8.0). The solution was electrophoresed in $1.2 \%$ agarose gel which had been stained with ethidium bromide $\left(0.4 \mu \mathrm{g} \mathrm{ml}^{-1}\right)$ for about $1.5 \mathrm{~h}$ at $80 \mathrm{~V}$. After then, the gel was photographed under ultraviolet light using GDS-760 image-analysis system (UVP)

\subsection{RAPD amplification}

One hundred decamer oligonucleotide primers (kit I ,
$\mathrm{H}, \mathrm{G}, \mathrm{M}$ and $\mathrm{N}$ ) for RAPD analysis were purchased from Operon Technologies Inc. (Alameda, CA , USA). These primers were used to amplify the control group and the cultivated groups respectively, selecting primers of more effectivity and dependable repeatability. DNA amplification was based on the protocol reported by Williams et al. (1990). $5 \mu \mathrm{l}$ of template DNA (20-25 ng) was amplified in $25 \mu \mathrm{l}$ PCR mixture consisting of $2.5 \mu \mathrm{l} 10 \times$ PCR buffer $2.5 \mathrm{mmol} \mathrm{L}^{-1} \mathrm{MgCl}_{2}, 2 \mathrm{mmol} \mathrm{L}^{-1} \mathrm{dNTP}$, $0.8 \mu \mathrm{mol} \mathrm{\textrm {L } ^ { - 1 }}$ primer and $1 \mathrm{U}$ Taq polymerase. For DNA amplification, PTC-100 DNA thermocycler was programmed for 4 min at $94{ }^{\circ} \mathrm{C}$; followed by 40 cycles of 1 min at $94{ }^{\circ} \mathrm{C}, 1 \mathrm{~min}$ at $36{ }^{\circ} \mathrm{C}, 2 \mathrm{~min}$ at $72{ }^{\circ} \mathrm{C}$, then terminating with $7 \mathrm{~min}$ at $72{ }^{\circ} \mathrm{C}$. The reactions were ended with an indefinite hold at $12{ }^{\circ} \mathrm{C}$. The RAPD fragments were separated on $1.2 \%$ agarose gel by electrophoresis in

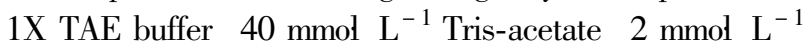
EDTA , pH 8) and stained with ethidium bromide. Finally, the gel was photographed under ultraviolet light using GDS-760 image-analysis system(UVP) .

1.4 Antioxidant enzymes extraction and activity determination

The extraction and activity determination of SOD , POD , CAT were measured spectrophoto - metrically according to the method of Trevor and Fletcher (1994).

\section{Results}

2.1 The morphological damage in Lemna minor L. leaves under $\mathrm{Hg}^{2+}$ stress

Lemna minor $\mathrm{L}$. is very sensitive to $\mathrm{Hg}^{2+}$, because its leaf is thin and in direct contact with water. After cultivated for $6 \mathrm{~d}$, the control group grew normally, while , the group treated with $5 \mathrm{mg} \cdot \mathrm{L}^{-1} \mathrm{Hg}^{2+}$ was already chlorotic from the edge of leaves, going with adventitious roots desquamation, and many black blotches and wilting occurred in the leaves treated with $7 \mathrm{mg} \mathrm{\textrm {L } ^ { - 1 }} \mathrm{Hg}^{2+}$. As far as the group treated with $20 \mathrm{mg} \mathrm{L}^{-1} \mathrm{Hg}^{2+}$ was concerned, a large number of dark-yellow and dead-speckles distributed in both edge and center of leaves, the leaf area constricted and raised in the center (Table 1) .

Table 1 External characters and comparision between the sensitivity of DNA Ladder and RAPD

\begin{tabular}{|c|c|c|c|}
\hline $\begin{array}{l}\text { Exposing concentration } \\
\qquad\left(\mathrm{Hg}^{2+}\right)\end{array}$ & External characters & $\begin{array}{l}\text { DNA Ladder } \\
\text { detection }\end{array}$ & $\begin{array}{c}\text { RAPD analysis } \\
\text { ( compared with the control group) }\end{array}$ \\
\hline CK & Leaves were green, adventitious roots were developed & - & - \\
\hline $5 \mathrm{mg} \mathrm{L} \mathrm{L}^{-1}$ & Leaves were chlorotic, adventitious roots desquamated & Not obvious & Distinct difference \\
\hline $7 \mathrm{mg} \mathrm{L} \mathrm{L}^{-1}$ & Leaf area constricted, adventitious roots desquamated & Obvious & Distinct difference \\
\hline $10 \mathrm{mg} \mathrm{L^{-1 }}$ & Leaves turned dark-yellow, adventitious roots desquamated & Clearer & Distinct difference \\
\hline $20 \mathrm{mg} \mathrm{L^{-1 }}$ & Leaves were necrotic, adventitious roots desquamated & $\begin{array}{l}\text { DNA was cleaved } \\
\text { randomly }\end{array}$ & Distinct difference \\
\hline
\end{tabular}




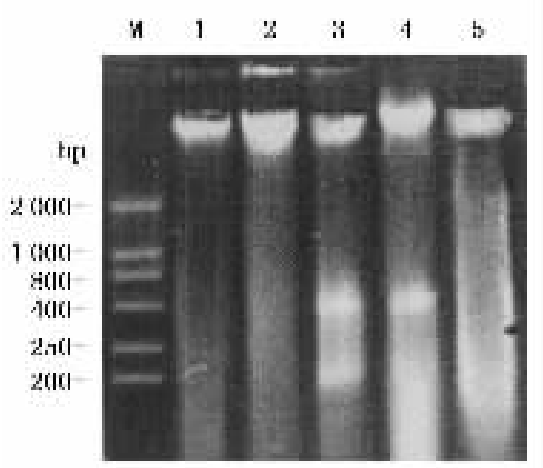

Fig. 1 Results of DNA damage presented by DNA Ladder method M :DNA marker ; 1 The control group 2 Treated with $5 \mathrm{mg} \mathrm{L}^{-1} \mathrm{Hg}^{2+}$ 3 : Treated with $7 \mathrm{mg} \mathrm{L}^{-1} \mathrm{Hg}^{2+} 4$ : Treated with $10 \mathrm{mg} \mathrm{L}^{-1} \mathrm{Hg}^{2+} 5$ : Treated with $20 \mathrm{mg} \mathrm{\textrm {L } ^ { - 1 }} \mathrm{Hg}^{2+}$

2.2 The DNA damage in Lemna minor L. leaves under $\mathrm{Hg}^{2+}$ stress

Through DNA Ladder detection, we found that the injury degree of DNA fragmentation was getting more serious with the rise of $\mathrm{Hg}^{2+}$ concentration. As shown in Fig. 1 , total DNA of the control group was a complete band, and no perceptible DNA Ladder could be seen in the group treated with $5 \mathrm{mg} \mathrm{L}^{-1} \mathrm{Hg}^{2+}$, either. However, DNA Ladder appeared with the increasing concentration of

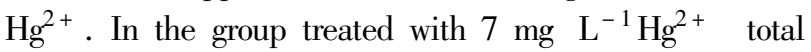
DNA was degraded into approximately $180-200 \mathrm{bp}$ and its multiples , and a typical DNA Ladder appeared on agarose gel electrophoresis. And DNA Ladder was more obvious when treatment concentration was $10 \mathrm{mg} \cdot \mathrm{L}^{-1} \mathrm{Hg}^{2+}$, which proved to be apoptosis. As far as the group treated with $20 \mathrm{mg} \mathrm{L}{ }^{-1} \mathrm{Hg}^{2+}$ was concerned, irregular break appeared on agarose gel electrophoresis. It seemed that total DNA had been cleaved randomly, which proved to be necrotic (Ryerson \& Heath ,1996) .

Through RAPD analysis, twelve of one hundred decamer primers ,OPI-03、OPI-06、OPI-12、OPI-17、OPH20、OPM-01、OPM-03、OPM-04、OPM-06、OPN-04、OPN05 and OPN-06 showed distinct polymorphic fingerprints between the control group and the contaminated ones (Table 2). The same results were obtained in the repeated experiments for three times. We supposed that the diversity of polymorphic fingerprints was resulted from the damage of DNA, not the differences between individuals of Lemna minor L. Take the group treated with $5 \mathrm{mg} \mathrm{\textrm {L } ^ { - 1 }}$ $\mathrm{Hg}^{2+}$ for example, after amplified by OPN-06, OPM-01 (Fig. 2, 1、2、7、8), DNA fragment reduced compared with the same site of the control group, which might because of DNA oxidative lesion, partial destroyed or strand breaks. Whereas, when amplified by OPN-04, OPM-06 (Fig. 2, 3、4、5、6), new DNA fragments appeared compared with those in control group, which might because of DNA mismatched, and so on. In brief, different primer could detect the different sites of primary structure damage in DNA.
Table 2 Sequence of random arbitrary primers used in the experiment

\begin{tabular}{cccc}
\hline Primer & Sequence $\left(5^{\prime}-3^{\prime}\right)$ & Primer & Sequence $\left(5^{\prime}-3^{\prime}\right)$ \\
\hline OPI-03 & CAG AAG CCC A & OPM-01 & GGT GGT GGC T \\
OPI-06 & AAG GCG GCA G & OPM-03 & GGG GGA TGA G \\
OPI-12 & AGA GGG CAC A & OPM-04 & GGC GGT TGT C \\
OPI-17 & GGT GGT GAT G & OPM-06 & CTG GGC AAC T \\
OPN-04 & GAC CGA CCC A & OPH-20 & GGG AGA CAT C \\
OPN-05 & ACT GAA CGC C & OPN-06 & GAG ACG CAC A \\
\hline
\end{tabular}

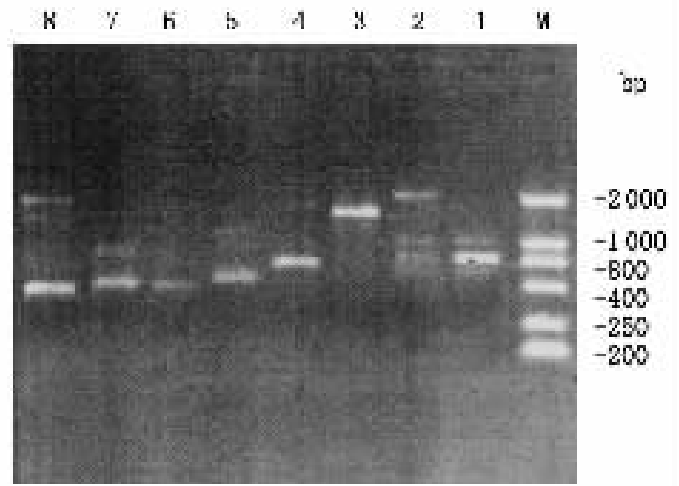

Fig.2 Results of DNA damage presented by RAPD method

M :DNA Marker 1,2 :OPN-06 3,4 :OPN-04 5,6 :OPM-06 7,8 : OPM-01, in which $1,3,5,7$ : Treated with $5 \mathrm{mg} \mathrm{L}^{-1} \mathrm{Hg}^{2+} \quad 2,4,6,8:$ : The control group

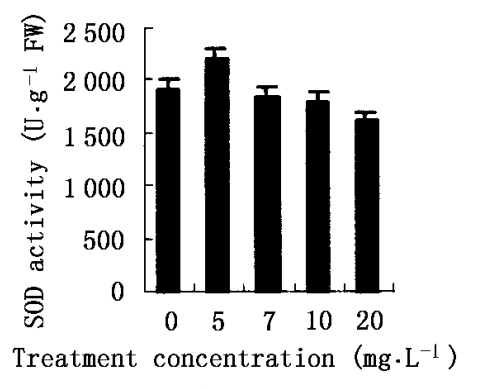

Fig.3 Effect of $\mathrm{Hg}^{2+}$ pollution on SOD activity

2.3 Changes of antioxidant enzyme activities in Lemna minor $\mathrm{L}$. leaves under $\mathrm{Hg}^{2+}$ stress

As can be seen from Fig. 3 , in the group treated with $5 \mathrm{mg} \mathrm{\textrm {L } ^ { - 1 }} \mathrm{Hg}^{2+}$, the activity of SOD reached the peak value, increasing by $15.66 \%$ of control. The SOD activity of the group treated with $7 \mathrm{mg} \mathrm{L}{ }^{-1} \mathrm{Hg}^{2+}$ was lower than that of the control group, and then it decreased markedly with the increasing of $\mathrm{Hg}^{2+}$ concentration $(R=$ $\left.-0.827, p<0.05^{*}\right)$. In the group treated with $20 \mathrm{mg}$ $\mathrm{L}^{-1} \mathrm{Hg}^{2+}$, the activity of SOD was only $85.14 \%$ of the control group.

As shown in Fig. 4 , the activity of POD increased slowly $\left(R=0.986, p<0.01^{* *}\right)$. When treated with 10 mg $\mathrm{L}^{-1} \mathrm{Hg}^{2+}$, it reached the peak , with $89.58 \%$ higher than that of the control. However, the group treated with $20 \mathrm{mg} \mathrm{L}^{-1} \mathrm{Hg}^{2+}$ declined to $80.71 \%$ of the control group.

As can be seen from Fig. 5 , the activity of CAT was 
more sensitive, it declined steadily with the increase of the $\mathrm{Hg}^{2+}$ concentrations. The CAT activity of the group treated with $5 \mathrm{mg} \mathrm{L} \mathrm{L}^{-1} \mathrm{Hg}^{2+}$ was $8.36 \%$ lower than that of the control group , and then it decreased rapidly $(r=-$ $\left.0.989, p<0.01^{* *}\right)$. In the case of the group treated

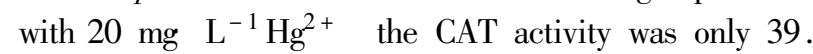
$13 \%$ of the control group.

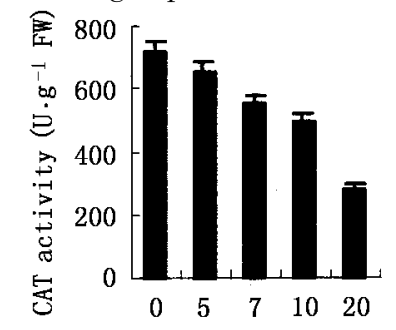

Treatment concentration $\left(\mathrm{mg} \cdot \mathrm{L}^{-1}\right)$

Fig.4 Effect of $\mathrm{Hg}^{2+}$ pollution on POD activity

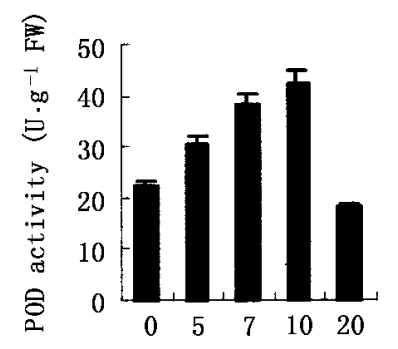

Treatment concentration $\left(\mathrm{mg} \cdot \mathrm{L}^{-1}\right.$ )

Fig.5 Effect of $\mathrm{Hg}^{2+}$ pollution on CAT activity

\section{Discussion}

The previous researches demonstrated that the method of DNA Ladder used in the detection of cells apoptosis in vitro was effective, because cells in vitro were similarly injured and cells apoptosis was induced simultaneously (Mengoni et al . 2000) . However, apoptosis of cells in vivo was induced in the different time, so apoptosis was detected difficultly by DNA Ladder detection. In our studies, DNA ladder could be detected easily during cell apoptosis of Lemna minor L. treated with 7-10 $\mathrm{mg} \mathrm{L} \mathrm{L}^{-1} \mathrm{Hg}^{2+}$. However, it almost couldn' t be detected in apoptosis induced by the concentration of $5 \mathrm{mg} \mathrm{\textrm {L } ^ { - 1 }}$ $\mathrm{Hg}^{2+}$. So in the case of low concentrations, we selected one hundred primers for RAPD analysis. The results showed that twelve primers could detect the damage of DNA. The reason was that the polymorphic DNA had been amplified by PCR, using appropriate random primers. Therefore, the DNA damage and diversity of polymorphic fingerprints could be detected rapidly by RAPD technology. It also was a sensitive method in detecting the damage of DNA primary structure during apoptosis of plant cells.

Many cells apoptosis could be induced by the accumulation of reactive oxygen species ( ROS), which had been suggested in many studies (Xia et al . 1999; ;u et al. 1996). There was an effective defense mechanism of antioxidation in cells, including SOD , CAT and POD , which could scavenge ROS out effectively. Cells could be in the normal condition when the balance was maintained between oxidation and antioxidation. Once the balance was disturbed, the function would be affected ,and which might lead to apoptosis. It was showed in our studies that $\mathrm{Hg}^{2+}$ at low concentration could cause a rapid increase of the anti-oxidant enzymes activity to scavenge the reactive oxygen, while the activity decreased distinctly when reactive oxygen exceeded a certain level, which would cause the plant cell apoptosis. The mechanisms of ROS' damage to organism mainly related to the damage of DNA , especially the oxidative damage of mtDNA (Zeng \& Zhang , 1995). The oxidative damages of mtDNA might cause some changes of the primary structure of DNA, such as base deletion, base modification and insertional mutagenesis, in which base deletion was more universal(Halliwell \& Aruoma ,1993). ROS can also induced nuclear DNA base deletion, base modification, single and doublestranded DNA breakage, interstand DNA cross-links and so on ( Lu et al . 1996). So we could propose that the appearance of DNA Ladder during cell apoptosis was likely concerned with ROS.

The latest studies abroad showed that heavy-metal pollution had a pronounced effect on the intrinsic DNA polymorphic fingerprints in RAPD analysis, namely the damage of DNA primary structure (Atienzar et al . 2001 ; Mengoni et al. 2000). Our studies showed that $\mathrm{Hg}^{2+}$ could result in the damage of mtDNA and nuclear DNA primary structure , such as nucleotide fragment lost, mismatched, and so on ( Fig. 1,2), and lead to cell metabolism disorder and cell apoptosis in the end.

\section{References}

Atienzar, F. A., V. V. Cheung, A. N. Jha \& M. H. Depledge. 2001. Fitness parameters and DNA effects are sensitive indicators of copper-induced toxicity in Daphnia magna. Toxicological Sciences, 59: $241 \sim 250$.

Halliwell, B. \& O. I. Aruoma. 1993. DNA and free radical. New York: Ellis Horwood Limited Press.

Korichera, J., S. Roy \& J. A. Vranjic. 1997. Antioxidant responses to simulated acid rain and heavy metal deposition in birchseedlings. Environmental Pollution, 95: 249 258 .

Lu, Y. (陆怡) , H. Z. Pan (潘华珍) \& C. M. Xu (许彩民). 1996. Oxidative stress induced apoptosis. Progress in Biochemistry and Biophysics (生物化学与生物物理进展), 23: 118 121. (in Chinese with English abstract)

Mengoni, A., C. Gonnelli, F. Galardi, R. Gabbrielli \& M. Bazzicalupo. 2000. Genetic diversity and heavy metal tolerance in populations of Silene paradoxa L. (Caryophyllaceae) : a random amplified polymorphic DNA analysis. Molecular Ecology, 9: $1319 \sim 1324$.

Meyer, S. L. F. \& M. C. Heath. 1988. A comparision of the death induced by fungal invasion or toxic chemical in cowpea epidermal cells. I . Cell death induced by heavy metal salts. Canadian Journal of Botany, 66: $613 \sim 623$. 
Rogers, S. D. \& A. J. Bendich. 1985. Extraction of DNA from milligram amounts of fresh, herbarium and mummified plant tissues. Plant Molecular Biology, 5: $69 \sim 76$.

Ryerson, D. E. \& M. C. Heath. 1996. Cleavage of nuclear DNA into oligonucleosomal fragments during cell death induced by fungal infection or by abiotic treatments. Plant Cell, 8: $393 \sim 402$.

Schutzendubel, A. 2001. Cadmium-induced changes in antioxidation systems, hydperoxide content, and differentiation in Scots pine. Plant Physiology, 127: $887 \sim 898$.

Shi, G. X. (施国新) , K. H. Du (杜开和) \& K. B. Xie(解凯 涁). 2000. Ultrastructural study of leaf cells damaged from $\mathrm{Hg}^{2+}$ and $\mathrm{Cd}^{2+}$ pollution in Hydrilla verticillata. Acta Botanica Sinica (植物学报), 42: $373 \sim 378$. (in Chinese with English abstract)

Sugiyama, M. 1994. Role of cellular antioxidants in metal-induced damage. Cell Biology and Toxicology, 10: 1 22 .

Tong, Z. 1997. Use of duckweed ( Lemna minor L.) growth inhibition test to evaluate the toxicity of acrylonitrile, swlphocyanic, sodium and acetonitrile in China. Environment Pollution, 98: $143 \sim 147$.

Trevor, E. K. \& R.A. Fletcher. 1994. Paclobutrazd protects wheat seedlings from heat and paraquat injury is detoxification of active oxygen involved? Plant Cell Physiology, 1: $45 \sim 52$.
Williams, J. G., A. Kubelik, K. Livak, J. Rafalski \& S. Tingey. 1990. DNA polymorphisms amplified by arbitary primers are useful as genetic markers. Nucleic Acids Research, 18: 6531 $\sim 6535$

Wu, Y. Y. (吴燕玉), X. Wang (王新) \& R. L. Liang (梁仁 禄). 1997. Ecological effect of compound pollution of heavy metals in soil-plant system II . Effect on element uptake by crops, alfalfa and tree. Chinese Journal of Applied Ecology (应 用生态学报)，8: $545 \sim 552$. (in Chinese with English abstract)

Xia, H. L. (夏慧莉), H. M. Chen(陈浩明), Y. Wu(吴逸) \& Y. R. Dai(戴尧仁). 1999. Hydroxyl radicals induce apoptosis of tobacco cells. Acta Phytophysiologica Sinica (植物生理学 报), 25: 339 342. (in Chinese with English abstract)

Zeng, Z. H. (曾昭惠) \& Z. Y. Zhang (张宗玉). 1995. The oxidative damage of mitochondrial DNA by free radicals and aging. Progress in Biochemistry and Biophysics (生物化学与生物 物理进展), 22: 429 432. (in Chinese with English abstract)

Zhang, Y. X. (张玉秀), T. Y. Chai (柴团耀) \& B. Gerard. 1999. Research advances on the mechanism of heavy metal tolerance in plants. Acta Botanica Sinica (植物学报), 41:453 457. (in Chinese with English abstract)

责任编委 : 林植芳 责任编辑 : 姜联合 